\title{
Local Democracy and the Consideration of Community Views: Obligation and Observance
}

\author{
Dean R Knight*
}

\section{Introduction: Local Government as Grassroots Democracy}

Local government is, at least in aspirational terms, all about "the peoples". The very raison d'être of local government is the facilitation of citizen participation and local self-government. The famous Widdicombe report United Kingdom's parliamentary inquiry into the conduct of local authority business - marked out "participation" as one of the three valuable attributes of local government, along with pluralism and responsiveness: ${ }^{1}$

Local government offers two kinds of participation; participation in the expression of community views and participation in the actual delivery of services. It does so both through the process of electing representatives as councillors and through the opportunity to influence local government more directly through consultation, co-option, and local lobbying.

In a similar vein, an earlier inquiry also emphasised the importance of the democratic features of local government, over and above its role as a provider of services. ${ }^{2}$ Local government provides the means by which people "can take an active and constructive part in the business of government; and can decide for themselves ... what kind of services they want and what kind of environment they prefer". ${ }^{3}$ Nowadays the reference to government (the formal institutions of the state) has been replaced with the more fashionable term governance (the wider collaborative process of decision-making) in order to reinforce the

* Senior Lecturer, Faculty of Law and Associate, New Zealand Centre for Public Law, Victoria University of Wellington (dean.knight@vuw.ac.nz).

I would like to thank, subject to the usual caveat of my ultimate responsibility, Eddie Clark, Chris Mitchell and the anonymous referee for comments on draft versions of this chapter, along with Jonathan Glendenning and Conrad Reyners for research assistance.

1 Report of the Committee of Inquiry on the Conduct of Local Authority Business (1986) at [3.11] and [3.20]. See discussion in Kenneth A Palmer Local Government Law in New Zealand (2nd ed, Law Book Company, Sydney, 1993) at 23.

2 Report of the Royal Commission on Local Government in England 1966-69 (1969) at 10. See Palmer, ibid, at 25.

3 Local Government in England, ibid. 
centrality of the citizenry to the affairs of the local state. ${ }^{4}$ Framed in this way, local governance better captures the idea that governance is "the joint work of government and civil society. . . [and] cannot be done by government alone". ${ }^{5}$ In more colloquial terms, the democratic essence of local government is sometimes captured in its description as grassroots or flaxroots decision-making, ${ }^{6}$ and the identification of neighbourhood as a "site of democracy". Some suggest there is much greater potential for political participation by citizens at a local, rather than central, level. ${ }^{8}$

In the New Zealand context, major reform of the local government framework in 2002 explicitly placed the notion of citizen participation at its heart. The reforms introduced a new statement of the purpose of local government. In addition to the substantive goal of promoting community well-being, ${ }^{9}$ local government is charged with enabling "democratic local decision-making and action by, and on behalf of, communities". ${ }^{10}$ This lodestar is buttressed by a number of more specific principles and processes that aim to facilitate interaction between the citizen and the local state. ${ }^{11}$ Most significantly, the regime imposes a specific obligation on local authorities to take into account community views when making decisions. ${ }^{12}$ While the framework was further refined (and slightly softened) in $2010,{ }^{13}$ it continues to stand as a remarkable

4 See Robin Hambleton and Jill Simone Gross (eds) Governing Cities in a Global Era: Urban Innovation, Competition, and Democratic Reform (Palgrave Macmillan, New York, 2007) at 215, adopted by Royal Commission on Auckland Governance Auckland Governance Report (2009) vol 1 at 45. See also Ali Memon and Gavin Thomas "New Zealand's Local Government Act: A Paradigm for Participatory Planning or Business as Usual?” (2006) 24 Urban Policy and Research 135 at 135.

5 Robert J Oakerson "The Governance Effects of Metropolitan Reform: A Theoretical Inquiry" (paper presented to the DeVoe Moore Center Critical Issues Symposium "Decentralized Government: The Implications of Government Organization in Metropolitan Areas”, Florida State University, Tallahassee, October 2002) at 2, also endorsed by the Royal Commission, above $\mathrm{n} 4$.

6 Local Government Bill 2002 (191-2) (select committee report).

7 Michael Farrelly "Citizen Participation and Neighbourhood Governance: Analysing Democratic Practice” (2009) 35 Local Government Studies 387 at 388.

8 Geraint Parry, George Moyser and Neil Day Political Participation and Democracy in Britain (Cambridge University Press, Cambridge, 1992); see also Colin Copus "ReEngaging Citizens and Councils: The Importance of the Councillor to Enhanced Citizen Involvement" (2003) 29 Local Government Studies 32 at 36.

9 Local Government Act 2002, s 10(b), namely, "to promote the social, economic, environmental, and cultural well-being of communities, in the present and for the future" (sometimes described as "the four well-beings").

10 Local Government Act 2002, s 10 (a).

11 See below at $\mathrm{n} 34$.

12 Local Government Act 2002, ss 14(1)(b) and 78.

13 Local Government Act 2002 Amendment Act 2010. For background to these reforms, see Rodney Hide “Reforms to Help Keep Rate Rises Under Control” (press release, 28 October 2009); and Cabinet Paper "Local Government Transparency, Accountability, 
attempt to articulate - and, perhaps most importantly, express in legislative terms - a regime centred on "the peoples".

The purpose of this chapter is to explore this newly invigorated process of local governance and democracy. First, I examine the obligation(s). I identify the key elements of the new statutory scheme that enables citizen contribution and requires local authorities to have regard to community views. In highlighting the attempt to codify the processes of participation and associated judgements imposed on local functionaries, I attempt to place those new provisions within their broader context. Secondly, I turn to the observance of those obligations. I examine the approach adopted by the courts and other external bodies when supervising compliance with the various obligations, critiquing their treatment of this novel statutory scheme.

My ultimate conclusion is that while the obligation to consider community views has been framed in a careful, nuanced and somewhat novel manner, the courts have scrutinised the observance too aggressively, undermining the local authority discretion and judgement that was meant to temper this critical obligation. First, it is fair to say that the Local Government Act 2002 regime represents an ambitious attempt to locate the citizen and communities at the heart of local government decision-making. Community views are expected to inform the full gamut of neighbourhood decision-making, from its strategic direction to law-making to operational decision-making. The more significant the decision, the greater expectation that the community will participate in its development. The empowerment of citizen-input comes with an important gloss, though. The extent to which it is sought, and relied upon, remains a matter of judgement. The general principles approach, obligating local authorities to consider community views, can only work in an effective and efficient manner if the particular context of decision-making is acknowledged. The responsibility for that call has been ultimately delegated by Parliament to local politicians.

Secondly, the courts have struggled with their secondary task of supervising the observance of these obligations. The intensity they bring to the review of local authority decisions has varied. On the one hand, their approach has been relatively deferential when dealing with challenges to the strategic planning process, when questions are raised about whether the community properly had input in the development of the blueprint for their district. On the other hand, they have been very vigilant when scrutinising whether decision-making principles were observed at the individual decision-making level. I doubt whether the statutory scheme intended such a finicky eye and I question the 
adoption of aggressive supervision of legislative compliance. Such an approach was born, I think, in yesteryear when the boundaries and requirements of statutory schemes were drawn in more command and control terms. I worry that aggressive supervision of these obligations and moderating judgements risks juridifying this dynamic and complex evaluation. Juridification of the deliberative exercise risks judges, lawyers and technocrats dominating the process. This undercuts the political instinct of those who we elect to make decisions on our behalf and muddies the political accountability of those delegates to their local community.

This examination comes with a number of caveats. First, the focus is on the legislative opportunities for participation and engagement. It is not a sociological study of whether these opportunities are realised. Indeed, there is probably reason to be sceptical about the actual practice of participation by citizens; but that is a project beyond the scope of this chapter. While others have explored the input end of the local authority-citizen dynamic,,$^{14}$ there is little written on the output end, focusing on what local authorities do - or are legally required to do - with community views. Secondly, this chapter does not capture all the opportunities that exist for participation and engagement in local decision-making. My focus is on generic decision-making principles under the Local Government Act 2002, which is the particular area that was enhanced in the most recent reforms of local government. I do not address the opportunities for citizen participation in environmental rule-making and decision-making under the Resource Management Act 1991. ${ }^{15}$ Although the resource management regime represents a large portion of local authority decision-making (and, indeed, is still subject to the constraints of the generic decision-making and participation principles under the Local Government Act 2002), ${ }^{16}$ it contains particularised processes for public participation which have been examined elsewhere. ${ }^{17}$ That said, there is some analogy between the two regimes, particularly the attempt to set up a bald framework, only given life through the judgements of local authorities and application of higher-order

14 See Jean Drage (ed) Empowering Communities?: Representation and Participation in New Zealand's Local Government (Victoria University Press, Wellington, 2002); Local Government Commission Review of Local Government Act 2002 and Local Electoral Act 2001 (2008); Rhys Andrews and others "Supporting Effective Citizenship in Local Government: Engaging, Educating and Empowering Local Citizens” (2008) 34 Local Government Studies 489-507; Farrelly, above n 7; Copus, above n 8; UMR Research Barriers \& Enablers to Participate in Local Government (Department of Internal Affairs, Wellington, 2007).

15 Similarly, I do not address other regulatory regimes which impose specific participatory requirements. See however Laws of New Zealand Local Government (Reissue 1) at [140].

16 See Local Government Act 2002, s 16.

17 See generally Derek Nolan (ed) Environmental and Resource Management Law (4th ed, LexisNexis, Wellington, 2011), especially ch 3 and 4. 
purposes and principles. ${ }^{18}$ Finally, I do not address any of the peculiarities associated with the development of locality-specific legislation with the creation of a "super Council" for Auckland. ${ }^{19}$

\section{Analytical Approach: Obligation and Observance}

The Local Government Act 2002 introduced a new decision-making framework for all decisions made by local authorities. ${ }^{20}$ The purpose of the reform was to "[modernise] the way local authorities make their decisions, and to [enable] local authorities to work with their communities to meet the changing needs and aspirations of communities in the 21st century". ${ }^{21}$ The framework is multilayered, incorporating the following:

(a) an overarching purpose and high-level principles governing the performance of the role of local authorities;

(b) strategic planning processes; and

(c) individual decision-making principles, including the specific obligation to take into account community views.

When examining each of these types of decisions, I break my analysis into two parts. I first sketch the nature of the legislative obligation and the unique way it seeks to factor community views into decision-making by local authorities. I then examine how the courts and other public functionaries have policed these obligations. My examination includes a critique of the courts' approach, ultimately doubting whether the courts have realised the intentions of the novel statutory scheme.

My analysis focuses on the courts and other entities formally charged with monitoring compliance. They are not, of course, the only bodies responsible

18 See Janet McLean “New Zealand's Resource Management Act 1991: Process with Purpose?” (1989-1992) 7 Otago LR 538.

19 Royal Commission on Auckland Governance, above n 4; Local Government (Tamaki Makaurau Reorganisation) Act 2009; Local Government (Auckland Council) Act 2009; Local Government (Auckland Law Reform) Bill 2009 (112-1).

20 This section is partly based on the publication: Laws of New Zealand Local Government (Reissue 1). See also Grant Hewison The Local Government Act 2002 - Rationalisation or Reform (PhD Thesis, University of Auckland, 2008); Dean Knight "Local Authority Decision-making, Community Views, and Stadium Aotearoa" [2007] NZLJ 354; Sally Dossor “Local Government Act 2002 - Issues for RMA Lawyers" in Environmental Issues: Insight and Inspiration (New Zealand Law Society, Wellington, 2005); Christopher Mitchell and Dean Knight LexisNexis Local Government (looseleaf ed, LexisNexis) at [LGA75.1]-[LGA121.1].

21 Local Government Bill 2001 (191-1) (explanatory note) at 2. For a historical account of local authority decision-making and participation frameworks, see Christine Cheyne "Public Involvement in Local Government in New Zealand: A Historical Account" in Jean Drage (ed) Empowering Communities? Representation and Participation in New Zealand's Local Government (Victoria University Press, Wellington 2002) 116. 
for holding elected members, officers and local authorities accountable. In a formal sense, a number of external public functionaries like the courts, Auditor-General, Ombudsman and ultimately the relevant minister have some responsibility for ensuring that the legislative obligations are observed. ${ }^{22}$ But in this context, there are other equally important informal judges of compliance: ratepayers, media, fellow elected members and so forth. In this chapter, I concentrate on the former, although I acknowledge that the latter may be more powerful watch-keepers than their formal counterparts. Indeed, part of the thesis advanced in this chapter is the idea that the novel legislative scheme is as much designed to enable informal control, and that strict formal control has been inappropriately applied.

I have focused on the courts' approach to supervision of compliance because it is necessary to appreciate the manner in which the obligations are policed in order to understand the true nature of the obligations. The fact that Parliament has mandated and legislated certain requirements does not, by itself, answer the question of the degree of compliance expected by reviewing bodies. The standard of review adopted by these supervisory bodies varies in different contexts. ${ }^{23}$ One of the ways of thinking about the protean standard of review is in terms of a dynamic compromise between different schools of thought on the purpose of judicial review and the legitimacy of judicial intervention in certain situations. ${ }^{24}$ On the one hand, one school proclaims the rule of law and the importance of the courts to enforce compliance with the law strictly. This approach emphasises the ex post facto supervision by the courts designed to guard against the administration exceeding its legal bounds. On the other hand, the alternative school places greater weight on the separation of powers and is concerned about the limitations of judicial supervision. This school places more value on the need for institutional comity or respect, among other things, acknowledging the constitutional allocation of power by the legislature to public bodies or officials and the secondary or review role of the courts. It emphasises the importance of facilitating the operations of the state and improving the effectiveness and efficiency of governance, and it recognises the limitations of the judicial function. Further, it recognises the judicial role as one of a myriad of other accountability controls, and places more weight on the instrumental

22 See, particularly, the various intervention powers of the Minister of Local Government under Part 10 of the Local Government Act 2002.

23 Hickman explains this distinction in terms of the standard of legality (which frames the obligations for the decision-maker) and the standard of review (which captures the intensity that a reviewing body should bring to compliance): Tom Hickman Public Law after the Human Rights Act (Hart Publishing, Oxford, 2010) at 99.

24 See, generally, Carol Harlow and Richard Rawlings Law and Administration (3rd ed, Cambridge University Press, Cambridge, 2009) at 23; and Dean R Knight "Mapping the Rainbow of Review: Recognising Variable Intensity" [2010] New Zealand Law Review 393 at 412. 
significance of other ex ante, informal and internal controls of administrative power. Neither school dominates, though. The balance between the two - or the intensity of review ultimately adopted - is typically determined, as usual in public law, according to context.

The differences can be illustrated through a simple example, say, the question of whether a local authority has properly assessed the significance of a decision to construct a sports arena in a particular location. Those championing vigilance would point to the fact that Parliament has mandated significance as a legislative threshold requiring special treatment by local authorities. In some cases, it is a trigger for consultation. In other cases, it is one of the overarching factors in the moderating judgement. It is the job of the courts to ensure the law is followed. Therefore, the courts will examine whether local authorities have "correctly" assessed whether something is significant. ${ }^{25}$ If the judicial opinion is different from the local authority then the decision may be overturned. But those favouring restraint would emphasise that Parliament has principally delegated the task of assessing whether something is significant to local authority members. Matters of significance are better assessed by people at the coal-face, with expertise on such matters - not by judges in sterile courtrooms disconnected from the affected community. There are other processes and checks-and-balances within the system that promote compliance with the principles, such as the local community (immediately through their reaction and ultimately at the ballot box), the fourth estate, the bureaucratic processes internal to local authorities like officer analysis and recommendation, and the deliberative processes of the Council chamber. ${ }^{26}$

I have foreshadowed my doubts about whether it was the purpose of Parliament that strict scrutiny was meant to be brought to the task of judicial supervision of individual decision-making, a point I develop further following an examination of the scheme itself. ${ }^{27}$

25 Although from a different legislative context, these values dominated in Westfield (New Zealand) Ltd $v$ North Shore City Council [2005] NZSC 17; [2005] 2 NZLR 597, where the Supreme Court considered the proper approach for reviewing the sufficiency of evidence supporting the exceptions to public notification of resource consents.

26 These values were emphasised by the Court of Appeal in Wellington City Council v Woolworths New Zealand Ltd (No 2) [1996] 2 NZLR 537, where a very deferential standard was established for reviewing policy decisions about the allocation of the rates burden.

27 See Part V(B) Observance. 


\section{Purpose and High-level Principles}

\section{A Obligation}

At the highest level, local authorities are charged with giving effect, in relation to their region or district, to the "purpose" of local government. ${ }^{28}$ As mentioned earlier, the purpose of local government is codified in the following terms: ${ }^{29}$

(a) to enable democratic local decision-making and action by, and on behalf of, communities; and

(b) to promote the social, economic, environmental, and cultural wellbeing of communities, in the present and for the future.

This is the first formal attempt in New Zealand to articulate clearly a general vision for local authorities in the form of a purpose clause in a way that captures the essence of the local participation. Local government reforms in the late 1980s contained a more operational set of expectations about how local authorities would conduct their affairs, but only with weak, passive recognition of citizen participation (local authorities were directed to conduct their business in a manner "open to the public" and to ensure "local communities ... . [were] adequately informed about [their] activities"). ${ }^{30}$ The commanding placement of the views of communities in the modern version is to be commended.

A minor gloss was placed on this broad purpose by an amendment in 2010 . Local authorities are also now directed to "have particular regard to" the contribution that the certain listed "core services" make to its communities. ${ }^{31}$ This amendment was driven out of (ideologically informed) concerns that local authorities were undertaking activities at the margins of their competence that were of dubious value. ${ }^{32}$ When such concerns were first expressed, there was a concern that an attempt would be made to restrict the competence of local authorities, by requiring them to undertake only core services, the definition of which would ultimately be political and controversial. ${ }^{33}$ In the end, jurisdictional proscriptions did not eventuate and the significance of

28 Local Government Act 2002, s 11(a). The role of a local authority also includes the obligation to perform the duties, and exercise the rights, conferred on it by the Local Government Act 2002 or any other enactment: Local Government Act 2002, s11(b).

29 Local Government Act 2002, s 10.

30 Local Government Act 1974, s 223C(1).

31 Local Government Act 2002, s 11A. The prescribed core services are: (a) network infrastructure; (b) public transport services; (c) solid waste collection and disposal; (d) the avoidance or mitigation of natural hazards; (e) libraries, museums, reserves, recreational facilities and other community infrastructure.

32 See Hide, above n 13; Cabinet Paper “Local Government Transparency”, above n 13.

33 See Mike Reid “The Problem with Defining Core Services” (2009) 5(4) Policy Quarterly 45. 
core services was only made a mandatory relevant consideration - albeit with elevated weight.

At the next level down, local authorities are directed to comply with (viz, they "must" and "should") the following rather indeterminable imperatives: ${ }^{34}$

(a) to conduct their business in an open, transparent and democratically accountable manner and give effect to their identified priorities and desired outcomes in an efficient and effective manner; ${ }^{35}$

(b) to take account of community views; ${ }^{36}$

(c) when making decisions, to take account of the diversity of the community and its interests, the interests of future communities and the impact on the four well-beings; ${ }^{37}$

(d) to provide opportunities for Māori to contribute to decision-making processes; ${ }^{38}$

(e) to collaborate and co-operate with other local authorities; ${ }^{39}$

(f) to undertake commercial transactions in accordance with sound business practices; ${ }^{40}$

(g) to ensure prudent stewardship and efficient and effective use of their resources; ${ }^{41}$

(h) periodically to assess the risk of investing in commercial activities; ${ }^{42}$ and

(i) to adopt a sustainable development approach. ${ }^{43}$

The community views directive captures the importance of local authorities being cognisant of the views of its people, as well as acknowledging the existence of peoples, in their plural sense: "a local authority should make itself aware of, and should have regard to, the views of all of its communities". ${ }^{44}$ Pluralistic communities - both current and future - are also specifically recognised elsewhere. ${ }^{45}$ This is important, because a legal construct of "a district" and "a

34 The introductory wording of s 14(1) speaks in mandatory terms: "In performing its role, a local authority must act in accordance with the following principles."

35 Local Government Act 2002, s14(1)(a). See also ss 77 and 91-92.

36 Local Government Act 2002, s14(1)(b). See also s 78.

37 Local Government Act 2002, s14(1)(c). See also s 77.

38 Local Government Act 2002, s14(1)(d). See also s 81.

39 Local Government Act 2002, s14(1)(e). See also ss 15-17.

40 Local Government Act 2002, s14(1)(f). See also ss 100-101.

41 Local Government Act 2002, s14(1)(g). See also ss 10.

42 Local Government Act 2002, s 14(1)(fa), inserted by the Local Government Act 2002 Amendment Act 2010.

43 Local Government Act 2002, s14(1)(h). See also ss 10 and 77.

44 Local Government Act 2002, s14(1)(b) (emphasis added).

45 Local Government Act 2002, s 14(1)(c) provides that "when making a decision, a local authority should take account of: (i) the diversity of the community, and the community's interests, within its district or region; and (ii) the interests of future as well as current 
community" will rarely be apt. The diversity of communities within a district means that a local authority assumes an important coordinating and mediating function when making decisions within its district and when the views of its communities come into conflict.

The principles also mark a particular place for the views of Māori, albeit that the obligation is expressed in a structural and procedural fashion: "a local authority should provide opportunities for Māori to contribute to its decisionmaking processes". ${ }^{46}$ Notably, the target constituency of the obligation is framed in expansive terms. It does not limit the participation opportunity to tangata whenua ${ }^{47}$ nor does it incorporate a trigger based on the relationship of Māori with ancestral land and other taonga. ${ }^{48}$

Unsurprisingly, given the impossibility of achieving compliance with this extensive - and potentially countervailing - set of principles, a moderating mechanism is contemplated. If these principles or the elements of the four wellbeings conflict, local authorities are directed to resolve the conflict in accordance with the open and accountable process principle expressed in s 14(1)(a)(i). ${ }^{49}$ Thus, the regime adopts a process solution - and one that ultimately hinges on the accountability to citizen electors - to resolve the inevitable problem of multiple objectives.

Finally, it is worth noting that the Local Government Act 2002 also introduced the power of general competence for local authorities, giving them "full capacity" to undertake activities in the same manner as individuals and corporations. ${ }^{50}$ This reform was designed to reverse the presumption that local authorities were authorised only to undertake those specific functions delegated to them. In many respects, the reform was intended to avoid the narrow application of the ultra vires principle by the courts that had plagued English local government. ${ }^{51}$ The removal of any legal impediment of limited competence

communities; and (iii) the likely impact of any decision on each aspect of well-being referred to in section 10 ".

46 Local Government Act 2002, s14(1)(d) (emphasis added).

47 See discussion of the Select Committee on this point: Local Government Bill 2002 (191-2) (select committee report).

48 Compare Resource Management Act 1991, s 6(e). But see Local Government Act 2002, s $77(1)(\mathrm{c})$, which is tied to such relationships.

49 Local Government Act 2002, s 14(2).

50 Local Government Act 2002, s 12(2). See Cabinet Policy Committee "Review of Local Government Act: Paper 2: Purpose and General Powers of Local Government” (27 September 2001) POL (01) 265 at [18]-[31]. See, generally, Grant Hewison "A Power of General Competence - Should it be Granted to Local Government in New Zealand?" (2000-2003) 9 Auckland U L Rev 498.

51 See Hewison, ibid, at 504; Martin Loughlin Legality and Locality: The Role of Law in Central-Local Government Relations (Clarendon Press, Oxford, 1996) at 45; and Ian Leigh Law, Politics and Local Democracy (Oxford University Press, Oxford, 2000) at 38. 
therefore reinforces the autonomy of local authorities, allowing them to choose, in collaboration with their communities, the activities they wish to engage in.

\section{B Observance}

So far there has been no litigation that has been centred on the observance of the high-level principles imposed on local authorities. That is to be expected. While local authorities must comply with these high-level and open-textured principles, it is reasonable to expect that how those principles are observed and achieved will remain a matter of discretion and judgement for each local authority. The courts are unlikely to want to be drawn into the conundrums involved in trying to resolve the myriad of overarching principles.

It is expected that they will fence off these principles as being non-justiciable and point to the processes of political accountability as being the central control mechanism to enforce compliance. This deferential approach was deployed most famously in Mercury Energy $v$ Electricity Corporation of New Zealand $L t d$, where the Privy Council dismissed efforts to overturn decisions of a stateowned enterprise based on similar high-level statements of general principles. ${ }^{52}$ Review of compliance is unlikely in the absence of flagrant impropriety, such as bad faith, corruption and fraud, on the part of the local authority.

These principles, therefore, set out some common themes that should inform local authority decision-making and actions. But they are framed at a level of abstraction, which means that the ability for citizens to rely on them to facilitate participation is limited. However, these principles are connected with a number of other more tangible participation injunctions that are integrated into the relevant decision-making processes and specific powers throughout the Act.

\section{Strategic Planning}

\section{A Obligation}

At the next level down from the general purpose and high-level principles, the Local Government Act 2002 translates the hortatory set of principles into a set of strategic planning processes that seek to embrace community aspirations. The long-term strategic focus is one of the central features of the Local Government Act 2002,53 although some longer-term financial planning processes were evident in the new public management reforms in the mid1980s. ${ }^{54}$ The Local Government Act 2002 requires the production of a number

52 Mercury Energy Ltd $v$ Electricity Corporation of New Zealand Ltd [1994] 2 NZLR 385.

53 See Memon and Thomas, above n 4, at 136.

54 See Local Government Act 1974, Part 7A-7C, Palmer, above n 1, at 294-311; Janet McLean "New Public Management New Zealand Style" in Paul Craig and Adam Tomkins (eds) 
of specifically mandated planning documents in collaboration with a local authority's community. The product of this reflective planning exercise - the long-term plan - is then adopted as the blueprint for the future activities of the local authority.

As originally enacted, the apex of the strategic planning process within the Local Government Act 2002 was the obligation to carry out a process every six years to identify community outcomes for the immediate and long-term future of their region or district. ${ }^{55}$ "Community outcomes" were originally envisaged as the community's desired outcomes (or "priorities for the time being") in terms of its current or future social, economic, environmental or cultural wellbeing, as identified through the community outcomes process or subsequently identified. ${ }^{56}$ No particular process was prescribed, ${ }^{57}$ but it was suggested the vision was that this process would be bottom-up and community-led rather than being dominated by the local authority itself. ${ }^{58}$ The outcomes were then to be fed into planning and reporting processes through the description of the community outcomes in the long-term plan. Memon and Thomas explain the original purpose in this way: ${ }^{59}$

The strategic cornerstone of the community plan is the set of community outcomes identified by communities . . . Community outcomes are expected to provide a means to guide priorities in relation to the activities of the local authority, central government and other service delivery organisations, to promote more effective deployment of resources and coordination amongst service providers and a basis to measure progress towards achieving outcomes.

While community outcomes remain an important feature of the strategic planning framework, the way in which they were required to be generated and identified was diluted by amendments in 2010. The definition of community outcomes was amended to "the outcomes that a local authority aims to achieve" in order to promote well-being, and the obligation to engage in a process to identify those community outcomes was removed. ${ }^{60}$ Community outcomes therefore still have a role in expressing the priorities of a district or region, but these priorities are more likely to be the expression of those priorities by elected members, rather than by the community itself. The community outcomes therefore are less reliable indicators of the priorities of the community-at-large.

The Executive and Public Law: Power and Accountability in Comparative Perspective (Oxford University Press, Oxford, 2006) 124.

55 Local Government Act 2002, s 91(1).

56 Local Government Act 2002, ss 5(1) and 91(2).

57 Local Government Act 2002, s 91(3).

58 Memon and Thomas, above $\mathrm{n}$ 4, at 137.

59 Ibid.

60 Local Government Act 2002, ss 5 and 91, as amended and repealed respectively by Local Government Act 2002 Amendment Act 2010, ss 4(1) and 13. 
The long-term plan is the cornerstone of local authority governance. ${ }^{61}$ Produced once every triennium and mandatory, the long-term plan sets out a local authority's vision and its proposed activities for the next 10 years. ${ }^{62}$ Its purpose is to encourage a long-term focus, enable public participation in the setting of priorities and provide a basis for accountability, as well as functioning as a "one-stop" shop for many governance policies and other matters. While the Local Government Act 2002 requires the inclusion of a broad set of information about the vision and proposed activities, the degree of detail is subject to a local authority's moderating judgement. ${ }^{63}$ On a year-by-year basis, the long-term plan is supported by the annual plan, which translates the 10-year vision into an annual programme for the fiscal appropriation of funds for a local authority. ${ }^{64}$ The annual plan is teamed with an annual report, which must compare the actual activities and performance of the local authority against its intended activities and performance. ${ }^{65}$

The requirement to adopt the long-term council community plan through the special consultative procedure (a formal and prescriptive form of consultation) provides the community with the opportunity to participate in the agendasetting process of the local authority. ${ }^{66}$ Once adopted, the plan operates as the "formal and public statement of the local authority's intentions". ${ }^{67}$ However, a local authority is not obligated to undertake activities in its plan; with some notable exceptions, it can make decisions inconsistent with it provided it identifies the inconsistency and resolves to later amend the plan. ${ }^{68}$ Effectively, the long-term council community plan authorises the listed activities and allows a local authority to undertake those activities as if they were an ordinary decision without any more enhanced public participation.

61 The plan was originally called "long-term council community plan" (commonly described as the LTCCP) but was refined in 2010: Local Government Act 2002 Amendment Act 2010, s 49.

62 Local Government Act 2002, s 93 and Sch 10, Part 1.

63 A local authority is obliged to include such details on these matters only as it considers on reasonable grounds to be appropriate (Local Government Act 2002, s 93(8)), and having regard to various other decision-making provisions (Local Government Act 2002, s 93(9)(a)).

64 See Local Government Act 2002, s 95(5).

65 See Local Government Act 2002, s 98(1); Local Government Act 2002, s 98(3); Local Government Act 2002, s 98(2). In the first year of the long-term council community plan period, the long-term council community plan operates as the annual plan: Local Government Act 2002, s 95(4).

66 Local Government Act 2002, s 95. For the requirements of the special consultative procedure, see text at 128 below.

68 Local Government Act 2002, s 96(1).

69 Local Government Act 2002, ss 80 and 96(2) and (3). For the exceptions, see text at n 71 below. 
Further, certain significant decisions (to commence or cease a significant activity, to alter significantly the level of service provision, or to transfer the ownership or control of a strategic asset to or from the local authority) cannot be undertaken unless they are "expressly provided for" in the local authority's long-term plan. ${ }^{69}$ If they are not, the requirement to amend the long-term plan triggers the opportunity for public participation through the special consultative procedure. Therefore this strategic planning requirement stands as an important gate-keeper for citizen participation. This gate-keeper role was, however, dramatically watered down by amendments in $2010 .^{70}$ The original list of decisions that needed to be provided for in the long-term plan was more extensive, also including a decision to change the mode of delivery of a significant activity; a decision to construct, replace or abandon a strategic asset; and a decision significantly affecting a local authority's capacity or cost in relation to activities in the long-term plan. ${ }^{71}$

Much of the impact of this gate-keeper provision turns on the meaning of "significant". The term "significance" is partially defined in the Local Government Act 2002: $:^{72}$

significance, in relation to any issue, proposal, decision, or other matter that concerns or is before a local authority, means the degree of importance of the issue, proposal, decision, or matter, as assessed by the local authority, in terms of its likely impact on, and likely consequences for, -

(a) the current and future social, economic, environmental, or cultural wellbeing of the district or region:

(b) any persons who are likely to be particularly affected by, or interested in, the issue, proposal, decision, or matter:

(c) the capacity of the local authority to perform its role, and the financial and other costs of doing so ...

In addition to this somewhat obtuse definition, a local authority is obliged to adopt its own policy on significance, through the special consultative procedure, setting out its general approach to determining the significance. ${ }^{73}$ Based on the

69 Local Government Act 2002, s 97.

70 For the rationale behind the reforms, see Cabinet Paper "Local Government Transparency", above $\mathrm{n} 13$.

71 Local Government Act 2002, ss 88 and 97(c) and (d), repealed by Local Government Act 2002 Amendment Act 2010, ss 12 and 15.

72 Local Government Act 2002, s 5. See also the definition of "significant" in s 5: "significant, in relation to any issue, proposal, decision, or other matter, means that the issue, proposal, decision, or other matter has a high degree of significance".

73 Local Government Act 2002, s 90. The policy must identify applicable thresholds, criteria or procedures to be used when assessing significance, as well as listing the assets considered by the local authority to be strategic assets. 
model promulgated by Local Government New Zealand, many local authorities have adopted significance policies that predominately express significance in terms of quantitative financial thresholds, along with minor reference to the qualitative degree of controversy of a proposal. ${ }^{74}$

Finally, decisions relating to key regulatory instruments, such as the making, amendment or revocation of a bylaw, can only be made through the special consultative procedure, ensuring the community is formally consulted about their promulgation. ${ }^{75}$

Looking at the strategic planning framework in the round, it is the key locus for the provision of community views. The long-term plan stands as the central strategic planning document and is expected to operate as a blueprint for individual local authority decision-making. It can be seen as the social contract between citizens and local politicians, incorporating the community's (or perhaps communities'?) aspirations and containing the portfolio of proposed activities that have been endorsed by the community through the special consultative procedure. Importantly, significant activities not identified cannot be undertaken without an amendment to the long-term plan, triggering an ad hoc participatory process where the views of the community must be sought through the special consultative procedure. The long-term plan therefore is another of the key procedural gate-keepers for the provision of community views.

But this is a particular area where the theory may not align with the practice. Many long-term plans contain volumes of financial data. The long-term plan can be an intimidating document for citizens to navigate and understand. While there is a great deal of work being done to improve the long-term plan documents and processes to enhance citizen participation, doubts remain about whether it provides a meaningful mechanism for citizens to contribute to the activities of local authorities. Further, the complex nature of the documentation means it is easy for some projects to get lost in the minutiae. ${ }^{76}$ At the end of the day, though, once an activity is expressly provided for in the long-term plan, the law regards the obligation of community input on the proposal as having been observed - even if endorsement by the subject community is only deemed and not real.

74 See Local Government New Zealand Local Government Knowhow Guide: Decision Making (LGNZ, Wellington 2004) at 120 and, for example, Wellington City Council Significance Policy (2006) <www.wellington.govt.nz>.

75 Local Government Act 2002, ss 83, 86 and 156.

76 See, particularly, Local Government Commission, above n 14, at 51. 


\section{B Observance}

To date, the challenges to strategic planning processes have been imprecise or collateral. There is not yet settled jurisprudence about how vigilantly the courts will police strategic planning obligations. The requirement to provide expressly for certain significant activities is likely to be scrutinised quite closely because of its function as a gate-keeper for public participation. This is analogous to similar gate-keeper provisions elsewhere. ${ }^{77}$ At the same time, the courts should avoid being too formalistic about this requirement, particularly where a previously authorised project morphs slightly in cost or design such that there are doubts about whether it is the same project as was expressly provided for in the long-term plan. In my view, the phrase "explicitly provided for" must surely have some latitude to deal with immaterial cost variances and other changes. ${ }^{78}$ Viewed in context as a mechanism for ensuring community input and mandate, the critical assessment needs to be about whether or not the views of the community would have been different if the otherwise configured project, rather than just quantitative tolerances, had been put to it. As the Auditor-General has sometimes stressed, it is important that the local authority has focused on and asked "the right question" of its community. ${ }^{79}$

It is difficult to yet read anything into the two cases that have most squarely confronted these issues. In Scott v Auckland City Council the High Court expressed some concern about whether these obligations were observed when the Auckland City Council was called on by the government to quickly express a preference about the site of a national rugby stadium. ${ }^{80}$ Before expressing a preference, the Council had undertaken an expedited two-week period of informal consultation. When considering a last-minute injunction application on the eve of the decision, Priestley J ruled that there was an arguable case "that the procedures which Part 6 requires [were] truncated and in some cases arguably ignored". ${ }^{81}$ The analysis was sparse, but undoubtedly the judge would have been concerned about whether the decision - either the mere expression of a community preference to the government or some more tangible financial involvement in construction - was significant and needed to be mandated

77 See, for example, Westfield (New Zealand) Ltd $v$ North Shore City Council [2005] NZSC 17; [2005] 2 NZLR 597.

78 Compare with the position at common law on any need to reconsult once options change: McInnes $v$ Minister of Transport [2001] 3 NZLR 11 and Contact Energy Ltd $v$ Electricity Commission HC Wellington CIV-2005-485-624, 29 August 2005.

79 Auditor-General Local Government: Results of the 2007/08 Audits (Office of the Auditor-General, Wellington, 2009) at [5.17].

80 Scott $v$ Auckland City Council HC Auckland CIV-2006-404-7226, 23 November 2006. For a more detailed discussion, see Knight "Local Authority Decision-making”, above n 20.

81 Scott $v$ Auckland City Council, ibid, at [35]. 
through the long-term plan process. There was also the question of whether vague references to stadium redevelopment in the long-term plan, along with some minor financial appropriation, meant the proposal was already expressly provided for. However, due to uncertainty about the precise nature of the proposal being considered by the Council (particularly whether the Council itself would be involved in the construction of the stadium) and the fact that rights to challenge the decision would still be available after the decision, interim relief was refused. It is difficult to draw too many conclusions from a hurried application for interim relief, but the approach hints at a degree of vigilance being applied to the strategic planning processes, even if the circumstances surrounding the court challenge prevented further examination of compliance.

In another challenge dealing with the construction of a stadium, Stop the Stadium Inc $v$ Dunedin City Council, ${ }^{82}$ the Court of Appeal was required to assess whether changes to costings and funding arrangements for the construction of the stadium meant the project was no longer the same project previously authorised in the long-term plan. The Court accepted that the capital cost had increased, but concluded that the total cost to the Council and average cost per ratepayer had "not significantly increased". ${ }^{83}$ Therefore the Court ruled that the project still fell within the ambit of the previous authorisation. The Court of Appeal's approach is curious. On the one hand, the Court approached the issue in a very technocratic manner, without endeavouring to locate the requirements within their broader democratic context. Approaching the issue in this formalistic manner suggests a vigilant approach to supervision of the performances of the obligations. On the other hand, the Court adopted a generous approach - arguably too generous - towards the local authority by ruling that any variation must be significant in itself before it fell outside its authorisation. This risks magnifying significance (that is, only significant deviations from significant activities are unauthorised) and sets the bar quite high for re-consulting the community on reconfigured proposals. While some latitude must be grafted on to the gate-keeper function, an approach that directly examines the effect of any change on the attitudes of the community to the project would have been preferable.

More litigation around the gate-keeper function of the long-term plan - its thresholds and tolerances - is expected in future, because the relatively strict and ostensibly objective nature of the strategic planning obligations means arguments about non-compliance will obtain some traction with the courts. Dissatisfied citizens will rightly see this as a key target when they consider that a local authority is undertaking activities without having secured a mandate from

82 Stop the Stadium Inc v Dunedin City Council [2009] NZCA 370. See a similar challenge in Walkerv Otago Regional Council HC Dunedin CIV 2009-412-352, 11 June 2009.

83 Stop the Stadium Inc v Dunedin City Council, ibid, at [56]. 
their community. While a vigilance approach is understandable, the courts will also need to be relatively circumspect. The assessment of significance involves a complex and contextual factual evaluation. It is a judgement, par excellence. Judges will never be as well placed as local elected members to assess such matters.

\section{$V$ Individual Decision-making Principles}

\section{A Obligation}

Putting the strategic planning processes aside, the Local Government Act 2002 also prescribes a number of decision-making principles for any decision made by a local authority. ${ }^{84}$ The enumerated principles require a local authority to do the following:

(a) to seek to identify all reasonably practicable options; ${ }^{85}$

(b) to assess:

(i) the costs and benefits of those options (in terms of the four community "well beings"); 86

(ii) the extent to which they promote or achieve community outcomes; ${ }^{87}$

(iii) the impact of each option on the local authority's capacity to meet present and future needs; ${ }^{88}$

(iv) any other relevant matters; ${ }^{89}$

(c) if any option involves a significant decision in relation to land or a body of water, to take account of the relationship of Māori and their culture and traditions with ancestral land, water sites, waahi tapu, valued flora and fauna, and other taonga; ${ }^{90}$

(d) to consider the views and preferences of people likely to be affected by, or who have an interest in, the matter (in other words, consider community views)..$^{91}$

To understand the shape of the obligations created by these principles, they can be examined by reference to their scope, content and tolerance.

In terms of their scope, these principles apply to all decisions, including a decision not to take any action. ${ }^{92}$ The comprehensiveness of these principles and

84 Local Government Act 2002, ss 76-81.

85 Local Government Act 2002, s 77(1)(a).

86 Local Government Act 2002, s 77(1)(b)(i).

87 Local Government Act 2002, s 77(1)(b)(ii).

88 Local Government Act 2002, s 77(1)(b)(iii).

89 Local Government Act 2002, s 77(1)(b)(iv).

90 Local Government Act 2002, s 77(1)(c).

91 Local Government Act 2002, s 78.

92 Local Government Act 2002, s 76(1) and (4). 
judgements is notable and can easily be lost sight of. Much of the focus on local authority is on decisions made by the governing body of the local authority; however, the provisions apply equally to decisions made by committees, subcommittees, officers or other delegates. Further, these decision-making processes and judgements must be followed for decisions regardless of the magnitude (or, rather, triviality) of the decision. The framework itself allows the magnitude of the decision to be taken into account in a quite nuanced manner and only demarcates "significant" decisions for special treatment. Finally, these processes and judgements also apply, to the extent not inconsistent, to decisions made under other regimes, also capturing regulatory decisions made under the Resource Management Act, Building Act, Reserves Act and the multiplicity of other legislation administered by local authorities. ${ }^{93}$

It is also notable that the principles crystallise into operation in two different ways. First, a local authority must ensure its processes promote compliance with the various requirements. ${ }^{94}$ This systematic obligation is framed in more aspirational terms. ${ }^{95}$ Its impact has not yet been measured. However, if its promise is fulfilled, this obligation may serve as a more powerful injunction for improving local decision-making and democracy. Secondly, every decision a local authority makes must be made in accordance with the enumerated principles. ${ }^{96}$ This is the instant obligation in the case of each and every decision and it is typically the obligation that forms the target for those who seek to impugn any particular decision. In particular, the requirements must be "appropriately observed" for significant decisions. ${ }^{97}$ While this suggests some latitude for decisions that are not significant, ${ }^{98}$ little has yet been made of the distinction. ${ }^{99}$

In terms of the content, the principles capture the community participation in a number of ways. There is, of course, the specific obligation to have regard to community views:

93 Local Government Act 2002, s 76(5). The provisions regulating decision-making under the Local Government Act 2002 do not limit any duty or obligation imposed under other legislation which imposes decision-making obligations: Local Government Act 2002, s 76(6).

94 Local Government Act 2002, s 76(3)(a).

95 Compare Resource Management Act 1991, s 5.

96 Local Government Act 2002, s 76(1).

97 Local Government Act 2002, s 76(3)(b).

98 It is interesting to note that the Select Committee specifically drew attention to the softer language and obligation in relation to decisions that are not significant: Local Government Bill 2001 (191-2) (select committee report) at 15.

99 The notable exception is Duffy J's discussion in Whakatane District Council $v$ Bay of Plenty Regional Council [2009] 3 NZLR 799 at [94]-[98], albeit in the context of the consequential question of whether a failure to follow the requirements would necessarily lead to invalidity. 


\section{Community views in relation to decisions}

(1) A local authority must, in the course of its decision-making process in relation to a matter, give consideration to the views and preferences of persons likely to be affected by, or to have an interest in, the matter.

The language of s 78 is perhaps somewhat odd. The operative language ("affected" and "have an interest in") hints at a narrow construction, but the breadth of the obligation is reinforced by the reference in the title to community views. However, community views are also added into the decision-making mix in other ways. The relevance of the views of Māori is emphasised, but only for "significant" decisions affecting land or bodies of water. The matters triggering the consideration of Māori interests have a strong pedigree in the Resource Management Act 1991, ${ }^{100}$ but are deployed here without the strong "shall recognise and provide for" injunction that elsewhere suggests a significant degree of weight be given to the interests of Māori. ${ }^{101}$ The procedural requirement to assess the proposal in terms of its promotion or achievement of community outcomes also integrates individual decision-making with the priorities identified as part of the strategic planning process.

Originally, this obligation arose at multiple stages throughout the decisionmaking process: the stage at which problems and objectives are defined, the stage at which reasonably practicable options are identified, the stage when those options are assessed and proposals adopted, and the stage when those proposals are adopted. ${ }^{102}$ However, the four-staged requirement was removed in 2010 and a local authority is now required to consider community views only "in the course of its decision making process" ${ }^{103}$ The temporal nature of the original obligation was quite far-reaching and, in part, was a common (and successful) target in litigation. ${ }^{104}$

The principles generate a number of mandatory relevant considerations. These impose procedural, not substantive, constraints on the decision-making process. Nothing particularly hinges on the slightly different injunctions used ("identify", "assess", "take account of", "consider"). ${ }^{105}$ It is axiomatic that the

100 Resource Management Act, 1991 s 6(e). Compare with other softer injunctions, framed in terms of mandatory relevant considerations only, used for the protection of some other Māori interests: Resource Management Act, ss 7(a) (kaitiakitanga) and 8 (Treaty of Waitangi).

101 See, for example, Takamore Trustees $v$ Kapiti Coast District Council [2003] 3 NZLR 496.

102 Local Government Act 2002, s 78(2).

103 Local Government Act 2002, s 78(2) was repealed by Local Government Act 2002 Amendment Act 2010, s 9.

104 See the analysis of the stages of decision-making in the Council of Social Services and Whakatane District Council cases: see text at n 137 and n 156 below.

105 Although it is sometimes said that the different relevancy formulations like "have regard to" and "take into account" might suggest a different level of obligation (see, for example, 
weight to be given to these considerations and whether they materially influence the ultimate decision remains a matter for the local authority itself. ${ }^{106}$ As a simple example, if a local authority's entire community is against a project, the local authority may still proceed with the project - all it needs to do is be cognisant that it is acting contrary to the wishes of its community.

The specific decision-making principles are augmented by the high-level principles of local democracy. The high-level principles apply both directly (through the generic obligation imposed on a local authority to "act in accordance with" them when performing its role) ${ }^{107}$ and indirectly (through the obligation to have regard to them when making judgements about the degree of compliance with decision-making principles). ${ }^{108}$

Finally, specific provision is made for tolerance, even though the enumerated principles are expressed only in terms of relevancy. The Local Government Act 2002 subjects the principles to explicit moderating judgements. That is, local authorities are entitled to make judgements about how to achieve compliance with these principles: ${ }^{109}$

79 Compliance with procedures in relation to decisions

(1) It is the responsibility of a local authority to make, in its discretion, judgments (a) about how to achieve compliance with sections 77 and 78 that is largely in proportion to the significance of the matters affected by the decision; and

(b) about, in particular,-

(i) the extent to which different options are to be identified and assessed; and

(ii) the degree to which benefits and costs are to be quantified; and

(iii) the extent and detail of the information to be considered; and

(iv) the extent and nature of any written record to be kept of the manner in which it has complied with those sections.

The factors relevant to the judgement made about the degree of compliance are also expressly identified: ${ }^{110}$

(2) In making judgments under subsection (1), a local authority must have regard to the significance of all relevant matters and, in addition, to -

(a) the principles set out in section 14 [that is, the high-level principles]; and

$R v$ CD [1976] 1 NZLR 436), any distinction seems unreal and otiose (see, for example, Te Runanga o Raukawa Inc $v$ Treaty of Waitangi Fisheries Commission CA 178/97, 14 October 1997).

106 See Scott v Auckland City Council, above n 80, at [26]. See also Office of the Controller and Auditor General Turning Principles into Action: A Guide for Local Authorities on Decision-making and Consultation (Wellington, 2007) at [3.39] and [5.27].

107 Local Government Act 2002, s 14(1).

108 Local Government Act 2002, s 79(2)(a).

109 Local Government Act 2002, s 79(1).

110 Local Government Act 2002, s 79(2). 
(b) the extent of the local authority's resources; and

(c) the extent to which the nature of a decision, or the circumstances in which a decision is taken, allow the local authority scope and opportunity to consider a range of options or the views and preferences of other persons.

The statutory language is relatively generous, allowing realistic judgements to be made in order to ensure administrative efficiency and effectiveness. The only substantive constraint is that any judgements made about how to achieve compliance should be "largely in proportion" with the significance of the proposal. While the sentiment underlying this constraint is sound, it is phrased in a curiously loose fashion - suggesting that a generous amount of latitude is expected to be applied. Ultimately, these moderating judgements are framed as a powerful regulator on the realisation of the community views imperative. However, as is developed more later, my view is that the courts have failed to give effect to this element of the statutory scheme and have insisted on strict compliance without adequate regard to this moderating provision. ${ }^{111}$

Returning to the framework as a whole, the consideration of community views is one of the central ingredients of the framework regulating individual decision-making by local authorities. The framework emphasises openness, public participation and community views. But public participation is not a singular concept. At an operational level it translates to an obligation to take into account community views. ${ }^{112}$ This obligation to have regard to community views is, in many respects, a passive one. No process, method or mode for taking account of community views is prescribed, although the local authority is elsewhere obliged to ensure that its decision-making processes promote compliance with the obligation to take account of community views. The regime envisages that a local authority will design the particular means by which the views of the community are identified, in order that the procedural obligation is satisfied. As the Auditor-General has said, it is up to a local authority to "use its judgement as to how it informs itself of community views". ${ }^{113}$

In principle, ascertaining community views may be achieved through formal and informal means: ${ }^{14}$

Small local authorities generally feel that they know their community, often through elected member and staff networks. Some use e-technology to assist community interaction and engagement, particularly where communities are spread over a large area. Bigger local authorities usually use more formal methods and often have ongoing relationships or formal partnerships with ethnic or interest groups.

111 See below Part V (B) Observance.

112 Local Government Act 2002, s 76(3)(a).

113 Office of the Controller and Auditor General, above n 106, at [3.40].

114 Ibid, at [3.42]. 
There remains, however, some fixation with the formal opportunities by which community views are channeled into the decision-making process. Common opportunities include ordinary consultation processes, ${ }^{115}$ the special consultative procedure, ${ }^{116}$ the processes developed to provide opportunities for Māori to contribute to decision-making, ${ }^{117}$ a referendum or poll of electors, ${ }^{118}$ the opportunity for public delegations to address local authority meetings, ${ }^{119}$ and the right for a person affected by a decision to make written or oral submissions to the local authority under ordinary administrative law principles. ${ }^{120}$ Indeed, the role of elected members as representative delegates means they will be able to bring community views to the table themselves. However, the courts have been (unduly) reluctant to accept that this is sufficient to discharge the community views injunction. ${ }^{121}$

The legislation expressly disavows the notion that the community views imperative translates into a general obligation to consult: ${ }^{122}$ "A local authority is not required by this section alone to undertake any consultation process or procedure." However, as discussed later, the approach adopted by the courts in relation to the observance of this obligation risks elevating the obligation into exactly that: an obligation to consult. ${ }^{123}$

More generally, a local authority is required to consult about decisions only

115 Local Government Act 2002, s 82.

116 Local Government Act 2002, s 83.

117 Local Government Act 2002, s 81. For a decision of the particular issues relating to consultation with, and participation of Māori, see Janine Hayward (ed) Local Government and the Treaty of Waitangi (Oxford University Press, Oxford, 2003), especially Janine Hayward "Is Local Government a Treaty Partner?" 3; Martin Maguire "Consultation: A Case Study of Local Experience" 119; and Janine Hayward "Realising Potential: The Ways and Challenges Ahead" 173; and Christine Cheyne and Veronica Tawhai He Wharemoa Te Rakau, Ka Mahue. Maori Engagement with Local Government: Knowledge, Experiences and Recommendations (Massey University, Palmerston North, 2007). Cheyne's evaluation is grim: “There is still considerable disenchantment among Māori with local authority decision-making processes and there is serious underrepresentation of Māori elected members. The provisions of the Local Electoral Act 2001 appear to be inadequate and those in the Local Government Act 2002 are far from being fulfilled": Christine Cheyne "Local Government" in Raymond Miller (ed) New Zealand Government and Politics (4th ed, Oxford University Press, Oxford, 2007) 285 at 292. See also Local Government Commission, above n 17, at 78 .

118 Local Electoral Act 2001, s 9. A binding referendum, with variable prescribed majorities, is mandatory in relation to decisions to close down or transfer the ownership of small water services: Local Government Act 2002, s 131.

119 The opportunity for delegations to address the governing body or committees of a local authority is usually governed by standing orders: see Local Government Act 2002, s 27.

120 See GDS Taylor Judicial Review: A New Zealand Perspective (Butterworths, Wellington, 1991) at [13.04]-[13.06].

121 See text at n 156.

122 Local Government Act 2002, s 78(3).

123 See below Part V (B) Observance. 
if it is directed to under the Local Government Act 2002 or other legislation. ${ }^{124}$ However, a local authority may still choose to consult on a matter, even though it is not obliged to do so, in order to ascertain the views of its community. In either case, when undertaking a mandatory or voluntary consultation process a local authority is obliged to undertake that consultation in accordance with the prescribed principles of consultation, ${ }^{125}$ subject to discretionary judgements about the degree of compliance. ${ }^{126}$ The principles of consultation largely codify the common law consultation principles. ${ }^{127}$

The statutory scheme incorporates an off-the-shelf model for consultation: the special consultative procedure. ${ }^{128}$ The Local Government Act 2002 prescribes formal steps for this "notice and comment" process of public participation. ${ }^{129}$ The special consultative procedure must be followed when making certain decisions, ${ }^{130}$ but may also be voluntarily adopted as the means for identifying community views. ${ }^{131}$ Sometimes it is treated as being the "gold-standard" for consultation, but it is clear that consultation may be much more proactive and aggressive than the special consultative procedure. ${ }^{132}$

124 See, for example, decisions to adopt certain planning documents, significant decisions and the disposal of parks (Local Government Act 2002, s 138). Decisions under other legislation may also provide for enhanced participation, such as decisions on applications for resource consent under the Resource Management Act 1991 or decisions to alter the classification of reserve land under the Reserves Act 1977. In the case of the latter, these additional requirements are preserved by virtue of the Local Government Act 2002, s 76(6).

125 Local Government Act 2002, s 82. For a challenge made to a decision based on a truncated consultation process, see Scott $v$ Auckland City Council, above n 80. Although the Court accepted that there was an arguable case, it declined to grant injunctive relief because of uncertainties about the nature of the decision to be made.

126 Local Government Act 2002, s 82(3) and (4).

127 See Wellington International Airport $v$ Air New Zealand [1993] 1 NZLR 671.

128 Local Government Act 2002, s 83. The special consultative procedure subsumed the previous two formal consultation processes under previous legislation: see Local Government Act 1974, ss 716A (special consultative procedure) and 716B (special order).

129 The local authority must prepare a "statement of proposal", the content of which is prescribed depending on the nature of the proposal (generally the proposed new provisions, plan or rules, along with supporting explanation and evaluation). All proposed changes, along with a summary, must be made publicly available ahead of the decision. The public is then entitled to make written and oral submissions on the proposal. Following a public hearing, a decision is made to adopt, modify or reject the proposal. See Local Government Act 2002, s 83(1)(a)-(k). As the special consultative procedure amounts to consultation, the principles of consultation must also be complied with, subject again to the usual moderating judgements (Local Government Act 2002, s 82.

130 These decisions include the adoption or amendment of the long-term plan or annual plan (ss 84 and 85); the making, amendment or revocation of bylaws (s 86); and decisions that must be explicitly provided for in the long-term council community plan (see text above at $n$ 69).

131 Local Government Act 2002, s 87.

132 Local Government Act 2002, s 82(1), (3) and (5). 
Community views may also be ascertained through the most formal participatory method: a poll or referendum of citizens. The Local Electoral Act 2001 allows a local authority to direct its electoral officer to conduct a referendum on any matter relating to the services that are to be provided by the local authority, any policy of the local authority, any proposal relating to current or future activities or objectives of the local authority, or the current or future well-being of its region or district, and certain matters relating to representation. ${ }^{133}$ In addition, a few decisions can be taken only following a poll or referendum, ${ }^{134}$ and electors may demand polls on certain electoral matters. ${ }^{135}$ Such referenda or polls must be conducted in accordance with the requirements in the Local Electoral Act 2001. ${ }^{136}$

In summary, for ordinary decisions the statutory scheme attempts to structure local authority decision-making by imposing a number of mandatory relevant considerations, including the injunction to have regard to the views of the community. At the same time the scheme reserves the local authorities critical choices about how to ascertain those views, the extent to which they are integrated in the particular decision and, ultimately, the weight to be given to those views.

\section{B Observance}

Again, there has not been a flood of litigation seeking to overturn decisions of local authorities due to a failure to observe the obligations applicable to ordinary decision-making. This may be because the open-textured scheme and anticipated role of moderating judgements were expected to present formidable hurdles. However, two particular decisions have demonstrated a high degree of vigilance on the part of courts in this area - unduly so, in my view. These two cases can be contrasted with the more deferential approach adopted by the Auditor-General when engaging in a similar review of decisions.

In the first case, Council of Social Services $v$ Christchurch City, the High Court quashed a decision of the Council to increase rent of council housing by 24 per cent. ${ }^{137}$ The increase came on the back of rents being under constant review for over 10 years, with the Council initially not making any increases and then pegging increases to different inflation measures. The large increase in 2008 was driven

133 Local Electoral Act 2001, ss 9(1) (proposals generally), 19ZD (Māori wards or constituencies), and 31 (electoral systems).

134 See Local Government Act 2002, s 131 (decisions to close down or transfer the ownership of small water services).

135 Local Electoral Act 2001, ss 19ZB (Māori wards or constituencies), and 29 (electoral systems).

136 See Local Electoral Act 2001, Parts 2-4.

137 Council of Social Services in Christchurch/Otautahi Inc v Christchurch City Council [2009] 2 NZLR 123. 
by Council concerns that the current regime was insufficient to deal with future costs and a desire to ensure that the maintenance and provision of the housing portfolio was financially self-funding and sustainable. Local groups opposed the increase and the Council of Social Services challenged the decision arguing, among other things, that the Council failed to have due regard to community views. The High Court upheld the challenge for a number of reasons. First, the Court ruled that the Council had either failed to consider whether the decision was significant or that the Council erroneously concluded it was not significant. ${ }^{138}$ Council reports at the time did not record the significance of the proposed decision (even though the Council argued that elected members often took different views on significance than those adopted in reports prepared by officers). ${ }^{139}$ Secondly, the Court ruled that the Council failed to assess all reasonably practicable options, because it failed to explore plausible alternative options such as seeking government assistance. ${ }^{140}$ In the light of the Court's conclusion that the decision was significant, the Court said "a thorough analysis" of the reasonably practicable options was required - a rudimentary assessment that omitted reference to the plausible option of government assistance was inadequate in the Court's view. ${ }^{141}$ Finally, the Court ruled that the Council did not adequately consider community views or the views of affected persons before making the decision. ${ }^{142}$ In previous reviews there had been a history of views being provided by tenants and other groups, both formally and informally. Some addressed the meeting itself, wrote letters to councillors and signed a petition that was presented to the Council. But the Court said the Council failed to obtain the views of people affected at other critical stages of the process: particularly when options were identified and assessed, and proposals were developed. Chisholm J held that the Act mandated public participation throughout that process, particularly given the Court's view of the significance of the proposed decision. ${ }^{143}$

This case illustrates a very vigilant approach. It is hard to avoid the conclusion that the Court simply substituted its view for the view of the local authority on the critical factors, particularly the evaluation of whether the proposal was significant or not. Although the Court's conclusion was framed as failing to have regard to the significance of the matter, it seems clear that the Council had in fact taken the view that the decision was not significant. The Court's approach was effectively to apply a correctness standard to the evaluation of significance without respecting the judgement made by the local authority on

\footnotetext{
138 Ibid, at [38] and [40].

139 Ibid, at [37].

140 Ibid, at [64].

141 Ibid, at [62].

142 Ibid, at [93].

143 Ibid, at [96].
} 
that point. This is inconsistent with local authority autonomy, particularly in the light of the partly self-setting approach to the evaluation of significance. Further, the Court failed to give any real room for the crucial moderating judgements to operate. Despite evidence of a history of engagement by the local authority, where the views of the affected community were well-known by the local authority, the Court insisted on greater community participation in the formal process. Even though the Court acknowledged that the Council was not obliged to consult formally about the decision, ${ }^{144}$ the expectations set by the Court meant the Council could only have discharged its obligation to take account of community views after completing a consultation process. That is incongruous and inconsistent with the statutory scheme.

The second case, Whakatane District Council $v$ Bay of Plenty Regional Council, arose after the Whakatane District Council challenged the decision of the Bay of Plenty Regional Council to move its headquarters from within its district to Tauranga. ${ }^{145}$ The challenge to the Regional Council's decisionmaking process failed in the High Court, but on appeal to the Court of Appeal the District Council succeeded in having the decision to relocate quashed.

The Regional Council had questioned the appropriateness of its location in Whakatane since its formation in 1989, doubting whether it could effectively fulfil its regional functions from this location. A number of accommodation reviews over the last decade or so had investigated the possibility of relocation, but suggested no changes. In 2006, the Regional Council undertook another review and commissioned the consultancy firm Deloitte New Zealand to reassess the ideal location. Deloittes consulted with the regional councillors and mayors, and in November issued a report suggesting that the Council should relocate from Whakatane to Tauranga. The reasons given were not financial; rather, Deloittes indicated that it was strategically sensible to be located in Tauranga due to Tauranga's growing size, its status as the region's main urban hub and the inevitability of the need for a significant presence in the Bay of Plenty's western regions. The Regional Council agreed in principle to move and organised a number of workshops and meetings with staff, affected interest groups and local iwi. With the realisation that the proposal would need to be incorporated in the long-term plan, the Regional Council then formally consulted on the proposal through the special consultative procedure. Ultimately, in June 2007 the Regional Council amended its long-term plan to provide for relocation, as well as formally making the decision to relocate. ${ }^{146}$

144 Ibid, at [78].

145 Whakatane District Council v Bay of Plenty Regional Council [2009] 3 NZLR 799 (HC), and Whakatane District Council v Bay of Plenty Regional Council [2010] 3 NZLR 826 (CA).

146 Whakatane District Council (HC), ibid, at [27]. 
The main target of the challenge was the consideration of community views at the preliminary stages of the decision-making processes: at the problemdefinition and option-identification stages. The legislative scheme at that time required the consideration of community views at each of the four stages of decision-making. The District Council argued that the Regional Council had failed to consider community views at these preliminary stages, and even though there was formal participation in the later stages, ${ }^{147}$ once the decision in principle was made "the die was cast". ${ }^{148}$

In the High Court, Duffy J adopted a sympathetic approach. ${ }^{149}$ She emphasised the discretionary choices available to the Regional Council when constructing the "procedural template" for decision-making. ${ }^{150}$ Notably, she put significant emphasis in her judgement on moderating judgements and, in doing so, dismissed any suggestion that the local authority needed to record expressly these moderating judgements in the decision-making process. ${ }^{151}$ Armed with her benevolent lens, Duffy J concluded that the Regional Council did take account of community views at these stages (albeit as a matter of inference from the reports) and did consider reasonably practicable options at these stages (albeit implicitly or accidentally). ${ }^{152}$ In doing so, she did not confine herself to the formal record of decision-making. For example, she accepted that an officer's report discussing the level of significance and knowledge of community view contained "mistaken assessments" 153 and was not "a reliable indicator of what was known to the [Regional Council] at that time". ${ }^{154}$ Duffy J was prepared to consider, as an alternative, whether the decision-making obligations were "directory", not "mandatory", such that non-compliance would not necessarily invalidate a decision. ${ }^{155}$

On appeal, the Court of Appeal was much less sympathetic. ${ }^{156}$ Baragwanath $\mathrm{J}$ rejected a submission from the Regional Council that the decision-making process was "a dynamic one", where the stages of decision-making overlap,

147 The decision to move was ultimately consulted on through the special consultative procedure as the long-term plan was amended: ibid at [27].

148 Ibid, at [61].

149 Whakatane District Council (HC), above n 145.

150 Ibid, at [46].

151 Ibid, at [55].

152 Ibid, at [76].

153 Ibid, at [79].

154 Ibid, at [81].

155 Ibid, at [94]. Her Honour pointed to the primary obligation to "promote" compliance only and, for significant decisions, to ensure s 76(1) has been "appropriately observed": ibid, at [96]-[97]. Although the obligations had the "ring of mandatory requirements", she suggested that "a requirement for appropriate observation is not an absolute": ibid, at [98].

156 Whakatane District Council (CA), above n 145. 
and where decisions are constantly under review to meet "the vagaries of real life". ${ }^{157} \mathrm{He}$ indicated that the community view injunction involves two steps. First, a local authority must secure information as to such views and preferences, either directly or through its delegates. Secondly, such information must have been actually considered at the relevant stages. A local authority must be able to point to documentation or other proof demonstrating consideration of this information - accidental compliance was "inherently unlikely". ${ }^{158}$ His analysis was emphatic: "No document and no other evidence" was adduced to show that the Regional Council had given consideration to community view: ${ }^{159}$ "That is the simple end of the matter." 160

The Court of Appeal's approach is, in my view, too clinical. First, the translation of the community view obligation into two sub-parts, the first of which requires active steps to obtain information about community views, effectively translates the passive obligation to consider into an active obligation to consult. This is specifically disavowed by s 78(4). Secondly, the insistence on distinct proof of consideration is unrealistic and inconsistent with the statutory scheme. The moderating judgement in s 79 allows local authorities to make choices about the extent, detail and nature of the information considered and the written record, and generally "how to achieve compliance". While Baragwanath J warned against treating s 79 as a "dispensing provision", its relationship with s 78 is largely ignored. Further, placing the obligation on the local authority to demonstrate compliance undercuts the empowering philosophy of the legislative scheme and is inconsistent with the political character and process of the local authority decision-maker. Moreover, the insistence on traditional and tangible evidence ignores the dynamic and political nature of policy-laden decisionmaking. While any evidential void cannot create impunity for a local authority, the expectations about the extent and type of evidence need to be attenuated to reflect the statutory scheme and to avoid the onus of proving invalidity being turned on its head. Ultimately, the Court scrutinised the decision-making process through a vigilant lens designed for more traditional command and control decision-making, rather than a more benevolent lens suitable for the political character of local democracy.

By way of contrast, the Auditor-General calibrated its supervisory eye more realistically, in my view, when conducting an inquiry into Christchurch City Council's decision in July 2008 to purchase four central city properties. ${ }^{161}$ The decision to purchase the properties was made at a Council workshop

157 Ibid, at [67].

158 Ibid, at [73].

159 Ibid, at [74].

160 Ibid, at [75].

161 Auditor-General "Inquiry into Christchurch City Council's Five Property Purchases" (2009) Office of the Auditor General <www.oag.govt.nz>. 
and subsequent Council meeting in less than three days, without particular public participation. The Council moved quickly because it took the view that the integrated development of these properties was crucial to its Central City Revitalisation strategy and an expedited process was needed avoid their being sold to third parties for unsympathetic development.

When undertaking his review, the Auditor-General adopted a different - and more deferential - reading of the Act: " $[T]$ he Act clearly expects those decisions to be informed by the political and democratic context within which elected members operate". ${ }^{162}$ In his view, there was "a clear parliamentary direction that there should be substantial deference to appropriate judgements that a local authority makes", and "the appropriate assessment of significance in a given case is a subjective judgement by the local authority". ${ }^{163}$ In the particular circumstances, greater recognition was afforded to prior, informal knowledge about community views: "The knowledge acquired from [consultation on previous strategies and plans], coupled with an understanding of the current environment and the decision in question, may have given the Council a basis for gauging current community views at the time of making this decision." 164 Ultimately, the Auditor-General found no reason to interfere with the assessment of significance and accepted that the proposal did not need specific, lengthy and additional formal consultation.

Judicial supervision of individual decision-making has therefore been rather vigilant. Little, if any, deference is afforded to the judgements of local authorities in the context of the obligation to consider community views. A more benevolent approach has been adopted by the Auditor-General, when undertaking a similar review function.

\section{Conclusion: Innovative Obligation and Over-aggressive Supervision of Observance}

The decision-making and participation framework in the Local Government Act 2002 presents a novel legislative vision for sub-national decision-making and community engagement. Community preferences and views are expressly situated at the centre of all local authority decision-making. This makes explicit that which has always been implicit. Local government is an ideal vehicle for community participation in decision-making.

The Local Government Act 2002 represents an ambitious attempt to codify the means and extent to which community views should inform the decisions of local authorities. The community views imperative is set among an innovative and modern legislative scheme, where the elements of old-fashioned discretion

162 Ibid, at [2.2].

163 Ibid, at [2.4].

164 Ibid, at [4.10]. 
and judgement are committed to writing. Some people, including me, have suggested it is the "quid pro quo" for the more generalised purpose of local government and the power of general competence. ${ }^{165}$ But while the legislative text is now more complex and littered with directives, I am not necessarily convinced that the decision-making principles were intended to alter materially the essence of local democracy and decision-making. The decision-making principles and community views imperatives need to be set in their broader context, particularly as it relates to the parameters applying to individual decision-making.

In my view, the statutory scheme simply codifies the existing elected member or officer thinking processes and the values of public office seen throughout local and central government. It tries to capture the very raison d'être of local government that has implicitly guided elected members and local authority bureaucrats. Further, the regime seeks to make explicit the basic administrative law standards and doctrines that applied through the common law. Administrative law courts have always required decision-makers to act consistently with their statutory purpose, ${ }^{166}$ identify all relevant considerations to any decision, disregard irrelevant matters, ${ }^{167}$ have adequate information before them before they make a decision, ${ }^{168}$ and to act logically, in a deliberative, reasoned manner. ${ }^{169}$ In many respects, the statutory list of decision-making parameters is reflective of established practice and values.

While the Local Government Act 2002 introduced some new terms and a couple of new processes and documents (most notably the long-term plan), the essence of established local democracy and deliberation has not actually changed dramatically, save for the attempt to record these deliberative and participatory processes in a singular blueprint. Budget documents and rulemaking still go through a formal process of public participation. For other decisions, the continuum of deliberative formality and participation remains - a judgement needs to be made about how important the issue is. The most serious change is the formalisation of the few categories of most important decisions, requiring a community mandate through participatory processes. ${ }^{170}$ I suspect that in days gone by most local authorities would have regarded those as having fallen at the high end of the formality continuum and would

165 See Knight “Local Authority Decision-making”, above n 20; and Memon and Thomas, above $\mathrm{n} 4$, at 136 .

166 Unison Networks Ltd v Commerce Commission [2008] 1 NZLR 42 at [53], adopting Padfield $v$ Minister of Agriculture, Fisheries and Food [1968] AC 997.

167 CREEDNZ Inc v Governor-General [1981] 1 NZLR 172.

168 Westfield (New Zealand) Ltd $v$ North Shore City Council [2005] NZSC 17; [2005] 2 NZLR 597.

169 Wellington City Councilv Woolworths (NZ) Ltd (No 2) [1996] 2 NZLR 537.

170 See Part V Individual Decision-Making Principles. 
have expected that there would need to be a reasonable degree of public participation in their development.

Parliamentary material is generally consistent with this account. The Minister for Local Government noted the move "from a detailed, prescriptive form of law to one that is empowering and flexible". ${ }^{171}$ Her speech emphasised a move from legal to political accountability, empowering "local communities to exercise even greater control over their elected representatives". ${ }^{172}$ She also recorded the magnanimous nature of the statutory scheme: "[T]he councils must in future be driven less by the need for strict compliance with a detailed statute, and more by the need to deliver the results that local communities demand." 173 The Select Committee was anxious to ensure that the Bill provided for "proper community consultation and participation in decision-making" particularly given some "mistrust" about local authority decision-making. ${ }^{174}$ However, its commentary emphasised political - not legal - accountability. The high-level principles were said to "act as reminders to local authorities that they are accountable" and to "provide guidelines to communities for assessing the mode of operation of their councils". ${ }^{175}$ The Bill generally was explained as "empower[ing] communities", as well as councils, making local authorities "more accountable to their electors", and ensuring that their "decision-making processes are open to the influence and scrutiny of their communities". ${ }^{176}$ In rejecting submissions calling for the adoption of an appeal authority for local authorities, the Select Committee most clearly disclosed a preference for political accountability: "We consider it is not appropriate to have a body that has the power to overturn policy decisions by democratically elected councils. The recourse in those cases must be the ballot box." ${ }^{177}$

So, while the reforms introduced a statutory scheme that looked very different in legislative character to earlier versions, its revolutionary effect should not be overstated. The statutory scheme is more an innovative attempt to commit pre-existing values and judgements to writing (with some modest revision) in order to provide greater structure for local government decisionmaking.

The nature of the way in which the decision-making principles were codified does not suggest, in my view, a fundamental reconfiguration of the relationship between local authorities and supervisory courts. In fact, the scheme suggests

171 Sandra Lee (18 December 2001) 597 NZPD 14126. See also Local Government Bill 2001 (191-2) (select committee report) at 3.

172 Lee, ibid, at 14127.

174 Ibid.

174 Local Government Bill 2001 (191-2) (select committee report) at 3 and 14.

175 Ibid, at 9 .

176 Ibid, at 3 .

177 Ibid, at 16 . 
the empowerment of local authority decision-making, not the subordination of local authorities to stricter supervision and control. But that has not been how the supervision of the obligations has been exercised by the courts under the modern framework.

I have doubted whether it was the purpose of Parliament that strict scrutiny was meant to be brought to the task of judicial supervision. It is often argued that the need for strong judicial supervision only arises when there are limited or weak political controls on the exercise of power. ${ }^{178}$ But, here, the regime itself emphasises political judgement and seems to be designed more to enable informal accountability. It encourages bureaucratic discipline, provides councillors with a language to grapple with questions of participation and deliberation, and gives the media and the general public anchors by which they can seek to hold elected members accountable. The nature and strength of political accountability mean there is less need for aggressive legal accountability through judicial review.

Indeed, strong legal accountability comes at a significant cost - most significantly it has the potential to undermine the democratic pedigree of elected local representatives. Judges can never replicate the intimacy of local decision-making, where the representatives live and breathe the dynamics of the neighbourhood. While public participation obviously has its benefits, governmental efficiency and effectiveness is also important. As Thomas $\mathrm{J}$ in Waitakere City Council $v$ Lovelock reminds us, there are adverse sideeffects arising from over-juridifying and strictly enforcing decision-making obligations: ${ }^{179}$

$[\mathrm{O}]$ verly indulgent judicial intervention will inhibit administrators' efficiency in the performance of their statutory responsibilities. Administrators will constantly be looking over their shoulders apprehensive at the prospect of judicial review. The constant threat of such proceedings will make them overcautious or lethargic. Justice O'Connor of the United States Supreme Court has made this point with a short and entertaining fable ...:

"The centipede was happy, quite, until a toad in fun

Said, 'Pray which leg goes after which?'

This worked his mind to such a pitch,

He lay distracted in a ditch,

Considering how to run."

One would not willingly wish this fate upon administrators.

178 See, for example, Peter Cane Administrative Law (4th ed, Oxford University Press, Oxford, 2004) at 407.

179 Waitakere City Council v Lovelock [1997] 2 NZLR 385, at 414: quoting Sandra Day O'Connor "Reflections on Preclusion of Judicial Review in England and the United States” (1986) 27 Wm \& Mary L Rev 643 at 655. 
Juridification also leads to elected members seeing the decision-making framework as merely a source of risk, rather than as empowering their instincts and judgements. ${ }^{180}$ Presented with this legal risk, decisions about the nature and degree of public participation are then delegated to those with legal and technocratic skills: the lawyers and officials. Lawyers are invited to express opinions on the degree of significance. Officers tick boxes on compliance sheets. If we are serious about the purpose of local government to enhance community well-being then we should be concerned about the out-sourcing of these functions by local politicians.

In my view it is better that elected members be empowered to take responsibility for judgements about the degree of public participation in decision-making. Democratic healthiness and the extent of civic engagement form part of the community well-beings for which elected members ought to be held accountable politically rather than legally. Excessive judicial intervention muddies that accountability dynamic. At the end of the day, it is about letting local politicians be exactly that: local politicians.

180 For discussion of juridification of supervisory relationships within English system of local government, see Loughlin, above n 51, at 399. 